Asian J Agric \& Biol. 2022(1). $\mathrm{AJAB}$ DOI: 10.35495/ajab.2021.01.031

Original Article

\title{
Phenotypic evaluation of rice germplasm against Xanthomonas oryzae pv. oryzae and its in-vitro management through antibiotics
}

\author{
Aysha Khan ${ }^{1}$, Safdar Ali ${ }^{1}$, Muhammad Sajid ${ }^{2}$, Muhammad Ahmad Zeshan ${ }^{4}$, Rana Binyamin ${ }^{5}$, \\ Nadeem Ahmed ${ }^{3}$, Muhammad Usman Ghani ${ }^{6}$ \\ ${ }^{1}$ Department of Plant Pathology, University of Agriculture, Faisalabad, Pakistan \\ ${ }^{2}$ Department of Plant Pathology, Bahauddin Zakariya University, Multan, Pakistan \\ ${ }^{3}$ Department of Plant Pathology, MNS-University of Agriculture, Multan, Pakistan \\ ${ }^{4}$ Department of Plant Pathology, College of Agriculture, University of Sargodha, Pakistan \\ ${ }^{5}$ Department of Plant Pathology, University of Agriculture Faisalabad. Sub-Campus Burewala, Pakistan \\ ${ }^{6}$ Institute of Soil and Environmental Sciences, University of Agriculture, Faisalabad, Pakistan
}

Received:

January 18, 2021

Accepted:

May 09, 2021

Online First:

November 03, 2021

Published:

January 09, 2022
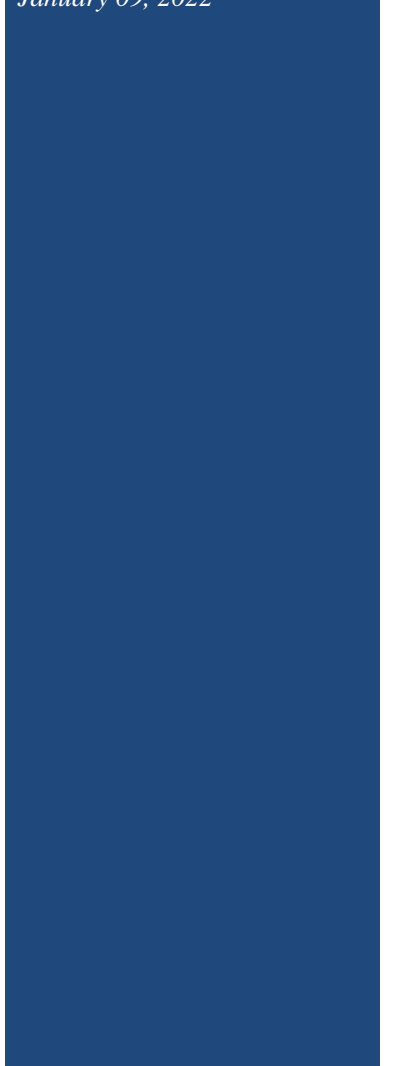

*Corresponding author email: muhammad.ahmad@uos.edu.pk

\begin{abstract}
Xanthomonas oryzae pv. oryzae (Xoo) which causes bacterial leaf blight (BLB) disease is one of the most destructive pathogen of rice. BLB incites more than $70 \%$ yield losses in epidemic conditions thus deteriorating the rice industry and export revenue. The use of conventional synthetic bactericides causes remarkable environmental hazards such as water and air pollution. This study was focused at the management of bacterial leaf blight disease through the application of antibiotics because injudicious use of bactericides results in the development of resistance in bacteria. The objectives were to evaluation of rice germplasm against BLB, biochemical characterization of the pathogen and its in-vitro management. There were very limited studies on the phenotypic evaluation of BLB disease and biochemical analyses of its causal organism. Twelve rice cultivars were screened against the disease in randomized complete block design. The isolated pathogen was subjected to Gram staining and microscopic examination. Biochemical characterization of the pathogen was done by methyl red, indole production, citrate utilization and Voges-Proskaure tests. Three antibiotics (Kanamycin, Streptomycin and Ampicillin) were used at three concentrations $(0,50,100$ and $150 \mathrm{ppm})$ against the pathogen. Among all the screened cultivars, none was highly resistant and resistant. Maximum disease severity $(89.01 \%)$ was depicted by the variety Super Basmati. All isolate were Gram negative and these showed positive response in case citrate utilization test indicating that citrate permeases enzyme is abundant. In-vitro results showed that Kanamycin is the most effective against pathogen at all concentrations than Ampicillin and Streptomycin. It is concluded that none of the screened cultivars showed resistance against Xoo, so the Basmati varieties may be sown with appropriate antibiotic like Kanamycin. It is recommended to devise effective breeding programs for the development of resistance rice cultivars against this economically important disease.
\end{abstract}

Keywords: Antibiotics, Xoo, In-vitro, Management, BLB

\section{How to cite this:}

Khan A, Ali S, Sajid M, Zeshan MA, Binyamin R, Ahmed N and Ghani MU, 2022. Phenotypic evaluation of rice germplasm against Xanthomonas oryzae pv. oryzae and its in-vitro management through antibiotics. Asian J. Agric. Biol. 2022(1): 202101031 DOI: https://doi.org/10.35495/ajab.2021.01.031

This is an Open Access article distributed under the terms of the Creative Commons Attribution 3.0 License. (https://creativecommons.org/licenses/by/3.0), which permits unrestricted use, distribution, and reproduction in any medium, provided the original work is properly cited. 


\section{Introduction}

Rice (Oryzae sativa L.), is the second most important staple food after wheat. Its exports are the secondhighest source of income in Pakistan (Cheng et al., 2020; Herawati et al., 2021). Rice yield is affected due to diseases like bacterial leaf blight (BLB) that poses huge qualitative and quantitative losses (Sere et al., 2005). Unfortunately, all varieties of Basmati are susceptible to BLB in Pakistan. BLB disease is accelerating in the latest years chiefly in the Kallar belt (Sheikhupura, Hafizabad, and Sialkot) which is known as high-quality rice-producing area in Pakistan (Khan et al., 2001). It was firstly reported in 1977 on rice Basmati-198, IR-6, Palman at Rice Research Institute Kala Shah Kaku, and some other farmer's field in Pakistan (Akhtar et al., 2008). Bacterial blight is viewed as an imperative illness in different parts of rice developing zones of Pakistan (Jabeen et al., 2012).The disease may destroy the seedling and in more established plants the loss of grain might be $4.5-29.1 \%$ (Shivalingaiah et al., 2013). There is a report of misfortune in rice trim because of blight up to 59-90\% (Rangarajan et al., 2003).

BLB is caused by Xanthomonas oryzae pv. oryzae (Xoo) that survives essentially in contaminated seeds, stubbles, straw, rations, and self-sown plants (Ahmed et al., 2020). The pathogen moves vertically through the leaf via primary veins. The vascular bundle of the plant is blocked by the physical presence and exudates of the bacteria which appear on the leaf surface as a characteristic sign (Nino-Liu et al., 2006). Xoo is a gram negative rod shaped bacteria with type III secretion system. It multiplies in xylem vessels and move systemically in plants (Furutani et al., 2009).

In-vitro screening of siderophore production by using Chrome Azurol S medium (CAS-medium) showed that 5 isolates were able to produce siderophore and it was confirmed by the development of orange halos surrounding those colonies (Manivannan et al., 2012). Seven isolates were found to produce more than $85 \%$ siderophore units (Tailor and Joshi, 2012). A subpopulation of 27 strains of plant associated with Pseudomonas fluorescens which could produce a compound and this compound inhibited the growth of the devastating rice bacterial blight pathogen Xoo in laboratory assays and suppressed rice bacterial blight up to 59-64\% in net-house and field experiments (Velusamy et al., 2006). Jeyalakshmi et al. (2010) found that the combination of seed treatment, soil application and foliar spray with $P$. fluorescens give the minimum disease incidence of bacterial leaf blight with maximum yield in comparison with the chemical treatment and control.

The evaluation of immunity status of available rice germplasm against BLB is an important step in the sustainable management of disease (Malukani et al., 2020). Furthermore, the biochemical characterization is the most pivotal tool to map out the disturbances incited by the pathogen which would otherwise be helpful in devising suitable management strategies. There are very scarce studies on the Xoo isolates of Pakistan regarding biochemical characterization, phenotypic evaluation and antibiotic efficacy.

Keeping in view the above mentioned facts, the present study was planned to elaborate different aspects of the Xoo including screening of rice germplasm against this pathogen, biochemical characterization of pathogenic isolate of BLB and invitro management of pathogen by using different antibiotics

\section{Material and Methods}

Screening of rice germplasm against bacterial leaf blight disease (BLB)

Experimental material and layout

Germplasm (Basmati-2000, Pak basmati, PS-2, Basmati-370, Super Basmati, Chenab basmati, Basmati-386, Punjab Basmati, Kisan Basmati, Basmati-385, Basmati-515 and Basmati-198) was collected from rice research institute Kala Shah Kaku. Randomized complete block design (RCBD) was used for the transplantation of nursery in the experimental field for screening of germplasm against the pathogen.

Table-1: Disease rating scale of $B L B$ of rice (Chaudhary, 1996)

\begin{tabular}{|l|l|}
\hline Highly Resistant & Less than 1\% of leaf affected \\
\hline Resistant & $1-10 \%$ of leaf affected \\
\hline Moderately Resistant & $11-30 \%$ of leaf affected \\
\hline Susceptible & $31-70 \%$ of leaf affected \\
\hline Highly Susceptible & $71 \%$ or more of leaf affected \\
\hline
\end{tabular}

\section{Disease assessment}

Disease severity of all the varieties was evaluated after the appearance of salient disease symptoms in the screening nursery. Plants from each variety were 
selected randomly and disease severity percentage was calculated in the field by using following formula;

$\%$ disease severity $=\frac{\text { No. of infected leaves } / \text { plant }}{\text { Total no. of leaves/plant }}$

All the varieties were classified according to the disease rating scale.

\section{Infected sample collection}

BLB infected leaf samples were collected from Hassanpura, Riazabad, Thatha Kher-o-Matmal, Sukheki Chowki, Tootra, Madryanwala, Hafizabad bypass, Fatehpur, Rasoolpur Tarar, Thatha Jehadka Tibba and Shah Behlool areas of district Hafizabad, Punjab, Pakistan.

\section{Preparation of nutrient agar medium}

Samples of infected leaves were preserved in refrigerator at $4^{\circ} \mathrm{C}$ for further processes. Nutrient agar media was prepared for the isolation of bacterial leaf blight pathogen (Xanthomonas oryzae pv. oryzae) from infected leaf samples (Basit et al., 2014).

\section{Isolation, identification and purification}

Infected leaves were dipped into $70 \%$ ethanol for surface sterilization for 2 seconds and then into distilled water for 2 seconds to wash out extraneous disinfectant. After this infected leaves samples were cut into 2-3 $\mathrm{mm}$ portions. Five pieces of infected leaves were placed on each media containing plate, four in front of each other and one in the centre of plate. Plates were kept in incubator at $25^{\circ} \mathrm{C}$ for 24 hours. After 24 hours Petri plates were examined with yellowish growth of bacteria on sides of the leave's cut portions. Isolated bacteria were characterized on the basis of colony formation pattern, color, size, distribution, and under UV light. Standard protocols of Koch's postulates were performed for the confirmation of pathogenicity.

Then a specific test for gram negative bacteria (Gram's staining) was done.

\section{Gram's staining}

Neat clean slide was taken and one drop of distilled water was put on it. By using a sterilized wire loop, small colony of bacteria was picked up and put on water; a thin film of a homogenous mixture was made. It was heat fixed by passing it 2-3 ties on a fire flame (avoid killing of bacteria due to extra heat).
Crystal violet stain was added on it for 60 seconds. Then by applying Lugol's iodine, it was washed for 60 seconds. Decolorization was done then by using pure acetone. Safranin was poured on it for 60 seconds which acted as a counter stain. Washed with distilled water at last and dried with a tissue paper. It was observed at 100x under microscope to confirm shape, size and distribution of bacteria (Bradbury, 1970).

\section{Biochemical characterization of pathogen}

Bacteria always produce some type of chemicals which are of great importance in characterization and identification of microorganism during some specific biochemical reactions (Klingler et al., 1992; Sultan et al., 2020).

These tests were performed in four different flasks. Initially, the ingredients of Methyl red test (Poly peptone, $\mathrm{K}_{2} \mathrm{HPO}_{4}$, Glucose and distilled water), Indole production test (Bactotrypton, $\mathrm{NaCl}$ and distilled water), Citrate Utilization test (Sodium ammonium phosphate, Sodium citrate, Potassium phosphate monobasic and Magnesium sulphate and distilled water), and Vogas Prosakure test (Poly peptone, $\mathrm{K}_{2} \mathrm{HPO}_{4}$, Glucose and distilled water) were mixed in different flasks as a media and poured in test tubes. Test tubes were autoclaved at $121^{\circ} \mathrm{C}$ at 15 psi for 15 minutes. Fresh and pure pathogen was inoculated to the medium with the help of inoculating loop. Test tubes were incubated at $35^{\circ} \mathrm{C}$ for 4 days. After this, for Methyl red test (Methyl red, Ethyl alcohol and distilled water), Indole production test (Para dimethyl amino benzaldehyde, Isoamyl alcohol and Hydrochloric acid), and Vogas Prosakure test (Alpha Napthol, Ethyl alcohol, KOH and distilled water) were mixed to prepare a reagent. After removing test tubes from incubator 3-4 drops of the respective reagent were added in these test tubes and let the biochemical reaction begun. After 15 minutes the color of the reactants were observed (Padmaja et al., 2017; Ahmad et al., 2020).

\section{In-vitro management of pathogen by using antibiotics \\ Pure culture of virulent strain}

An isolate was selected as most virulent on the basis of its most striking disease symptoms and high disease incidence and severity on pathogenicity test plants, rapid and most similar colony formation. Pure culture was prepared by using streaking method in Petri-dishes. It was subjected to evaluate different antibiotics at 
different dilution levels to check that which antibiotic is best against Xanthomonas oryzae pv. oryzae and at which level of concentration.

\section{Antibiotics}

Three antibiotics Kanamycin (Kanacillin Plain; manufactured by Fazul Ellahie (PVT) LTD.) Streptomycin (Streptomycin; manufactured by P.D.H. Pharmaceuticals (PVT) LTD.) and Ampicillin (Ampicillin; manufactured by Shifa Laboratories (PVT) LTD.) each at three levels of concentrations 50ppm, 100ppm and 150ppm. These concentrations were prepared by adding $50 \mathrm{mg}, 100 \mathrm{mg}$ and $150 \mathrm{mg}$ of the antibiotics in $1 \mathrm{ml}$ of distilled water.

\section{Poisoned food technique}

Nutrient agar was mixed in $1000 \mathrm{ml}$ distilled water and mixed thoroughly. It was autoclaved at $121^{\circ} \mathrm{C}$ for 15 minutes at 15 psi. After that media was cooled down and shifted into small bottles. Different concentrations of the antibiotics were mixed into the media bottles. Media was poured into petri plates which were labeled by antibiotic name, replication number, concentration levels and pathogen name etc. Petri plates were allowed to solidify and then with the help of inoculating loop freshly purified pathogen (Xanthomonas oryzae pv. oryzae) was inoculated. Petri plates were incubated at $30^{\circ} \mathrm{C}$ (Gholve and Kurundkar, 2007).

\section{Data recording}

Petri plates were observed and data was recorded at three intervals of time with the help on measuring scale. After 48 hours growth of bacteria on the inoculated petri plates was measured from the back side of petri plates with the help of scale then after 72 and 96 hours, respectively. The diameter of plate was measured and inhibition zone due to antibiotic application was recorded.

\section{Results}

\section{Screening of rice germplasm against bacterial leaf blight disease}

After three weeks of inoculation disease assessment data was collected and then till harvesting all the yield parameters were calculated. There was not even a single variety which found resistant against the pathogen. However, Pak Basmati, Kisan Basmati, Punjab Basmati, Chenab Basmati, Basmati 386 and Basmati-2000 were found susceptible while Super basmati, PS-2, Basmati 370, Basmati 515, Basmati 198 and Basmati 385 were found highly susceptible against BLB disease (Table 2).

Out of twelve varieties of rice tested in the field against bacterial leaf blight of rice Super Basmati was showing $(89.01 \%)$ disease severity followed by PS-2 showing (88.48\%) disease severity, Basmati-370 was showing $(80.55 \%)$ disease severity, Basmati-198 with (73.9\%) disease severity, Basmati-515 was with (73.4\%) disease severity, Basmati-385 was with (70.21\%) disease severity, Basmati-2000 was found with $(66.85 \%)$ disease severity, Basmati-386 with $(64.28 \%)$ disease severity, Pak basmati with $(54.69 \%)$ disease severity, Punjab basmati with (54.28\%) disease severity, Kisan basmati was showing $(47.11 \%)$ disease severity and Chenab basmati was showing (44.6\%) disease severity (Table 3 ).

Table-2: Response of rice germplasm against bacterial leaf blight of rice

\begin{tabular}{|c|l|l|}
\hline Sr. No. & \multicolumn{1}{|c|}{ Remarks } & \multicolumn{1}{c|}{ Varieties/Response } \\
\hline 1 & Highly resistant & \multicolumn{1}{c|}{0} \\
\hline 2 & Resistant & 0 \\
\hline 3 & Moderately resistant & \multicolumn{1}{c|}{0} \\
\hline 4 & Susceptible & $\begin{array}{l}\text { Chenab Basmati, Kisan } \\
\text { Basmati, Punjab Basmati, } \\
\text { Pak Basmati, Basmati- } \\
\text { 386, Basmati-2000 }\end{array}$ \\
\hline 5 & Highly susceptible & $\begin{array}{l}\text { Super basmati, PS-2, } \\
\text { Basmati-370, Basmati- } \\
515, \text { Basmati-198, } \\
\text { Basmati-385 }\end{array}$ \\
\hline
\end{tabular}

Table-3: Comparisons of means of disease severity among different rice cultivars

\begin{tabular}{|l|c|c|}
\hline \multicolumn{1}{|c|}{ Genotypes } & Disease severity (\%) & Response \\
\hline Super Basmati & $89.01 \mathrm{a}$ & HS \\
\hline PS-2 & $88.48 \mathrm{a}$ & HS \\
\hline Basmati-370 & $80.55 \mathrm{~b}$ & HS \\
\hline Basmati-198 & $73.90 \mathrm{c}$ & HS \\
\hline Basmati-515 & $73.40 \mathrm{c}$ & HS \\
\hline Basmati-385 & $70.21 \mathrm{~cd}$ & HS \\
\hline Basmati-2000 & $66.85 \mathrm{de}$ & $\mathrm{S}$ \\
\hline Basmati-386 & $64.45 \mathrm{e}$ & $\mathrm{S}$ \\
\hline Pak basmati & $54.69 \mathrm{f}$ & $\mathrm{S}$ \\
\hline Punjab basmati & $54.28 \mathrm{f}$ & $\mathrm{S}$ \\
\hline Kisan basmati & $47.11 \mathrm{~g}$ & $\mathrm{~S}$ \\
\hline Chenab basmati & $44.60 \mathrm{~g}$ & $\mathrm{~S}$ \\
\hline
\end{tabular}

*Means with similar letters are not significantly different from each other at $5 \%$ probability level $(\mathrm{LSD}=1.26)$ 


\section{Confirmation of pathogen by Koch's postulates and Gram staining}

Symptom development of the plants subjected to Koch postulates was observed after 4 weeks of artificial inoculation of bacteria to the selected plants. Plants which were inoculated with the pathogen isolated from the samples collected from Hassan Pura, Riazabad, Thata Kher-o-Matmal, Sukheki Chowki, Tootra, Madryan Wala, Hafizabad Bypass and Thatha Jehadka were showing highly developed and most obvious symptoms of BLB. Plants which were inoculated with the isolates of Fateh Pur samples were showing medium symptom development while plants inoculated with the isolates of the leaf samples of Rasoolpur Tarar and Tibba Shah Behlool were showing low symptom development.

Table-4: Gram staining and confirmation of pathogenicity by Koch's postulates

\begin{tabular}{|l|c|c|c|}
\hline \multicolumn{1}{|c|}{ Isolates } & $\begin{array}{c}\text { Gram } \\
\text { staining }\end{array}$ & $\begin{array}{c}\text { Disease } \\
\text { severity }\end{array}$ & $\begin{array}{c}\text { Symptom } \\
\text { development }\end{array}$ \\
\hline Hassan pura & Negative & $99 \%$ & High \\
\hline Sukheki chowki & Negative & $95 \%$ & High \\
\hline $\begin{array}{l}\text { Thatha kher-o- } \\
\text { matmal }\end{array}$ & Negative & $89 \%$ & High \\
\hline Hafizabad bypass & Negative & $87 \%$ & High \\
\hline Thatha jehadka & Negative & $78 \%$ & High \\
\hline Tootra & Negative & $71 \%$ & High \\
\hline Madryanwala & Negative & $62 \%$ & High \\
\hline Riazabad & Negative & $56 \%$ & High \\
\hline Fatehpur & Negative & $43 \%$ & Normal \\
\hline Rasoolpur tarar & Negative & $42 \%$ & Low \\
\hline Tibba shah behlool & Negative & $34 \%$ & Low \\
\hline Hassan pura & Negative & $99 \%$ & High \\
\hline
\end{tabular}

Plants inoculated with Hassan Pura isolates were showing high disease severity which was $99 \%$ following Sukheki Chowki with 95\% disease severity, Thatha Kher-o-Matmal with $89 \%$ disease severity, Hafizabad by pass with $87 \%$ disease severity, Thatha Jehadka with $78 \%$ disease severity, Tootran with $71 \%$ disease severity, Madryan Wala with $62 \%$ disease severity, Riazabad with $56 \%$ disease severity, Fatehpur with $43 \%$ disease severity, Rasoolpur Tarar with $42 \%$ disease severity and last was Tibba Shah Behlool with $34 \%$ disease severity (Table 4).

Gram's staining showed that all the tested isolates were found gram negative as a result of this staining test but they were showing some differences in the sizes from small to medium with uniform rod shapes.

\section{Morphology of colonies}

All the 11 isolates were observed and examined carefully. All the isolated pathogens were of yellow color and shape of colonies was circular with even margins. Sizes of colonies were medium to small and all the colonies were dark from center. Isolates of Hassan Pura, Thatha Kher-o-Matmal, Sukheki Chowki, Madryan Wala, Hafizabad Bypass and Thatha Jehadka were showing small colonies on nutrient agar plates. Isolates of Riazabad, Tootra, FatehPur, Rasoolpur Tarar and Tibba Shah Behlool were showing medium sized colonies grown on nutrient agar plates. All the isolates were having dark colored central portions of their colonies with the circular shape of colonies (Table 5).

Table-5: Colonial morphology of Xanthomonas oryzae pv. oryzae

\begin{tabular}{|l|c|c|c|c|}
\hline \multicolumn{1}{|c|}{ Isolates } & Color & Margins & Centre & Shape \\
\hline Hassan pura & Yellow & Even & Dark & Circular \\
\hline Riazabad & Yellow & Even & Dark & Circular \\
\hline $\begin{array}{l}\text { Thatha kher-o- } \\
\text { matmal }\end{array}$ & Yellow & Even & Dark & Circular \\
\hline Sukheki chowki & Yellow & Even & Dark & Circular \\
\hline Tootra & Yellow & Even & Dark & Circular \\
\hline Madryanwala & Yellow & Even & Dark & Circular \\
\hline $\begin{array}{l}\text { Hafizabad } \\
\text { bypass }\end{array}$ & Yellow & Even & Dark & Circular \\
\hline Fatehpur & Yellow & Even & Dark & Circular \\
\hline Rasoolpurtarar & Yellow & Even & Dark & Circular \\
\hline Thathajehadka & Yellow & Even & Dark & Circular \\
\hline $\begin{array}{l}\text { Tibba shah } \\
\text { behlool }\end{array}$ & Yellow & Even & Dark & Circular \\
\hline
\end{tabular}

\section{Biochemical characterization of pathogenic isolate of BLB}

To assess the biochemical characteristics possessed by the pathogen methyl red test, indole production test, citrate utilization test and Voges Proskaure test were conducted.

Methyl red test: All isolates showed negative response towards the test because the color they were showing was yellow.

Indole production test: All isolates showed negative response towards the test because the color they were showing was yellow. All the isolates of Xoo were not able to produce indole. 
Citrate utilization test: When test tubes were removed from incubator and color of the media was examined, it turned blue from green which showed that bacteria surviving in that medium were consuming carbon as food source from provided citrate compounds. It indicates that the bacteria were containing citrate permeases enzyme due to which they were consuming carbon from citrate compound.

Voges Proskaure test: When test tubes were removed from the incubator and color of each test tube was examined, they showed negative response toward test because there was yellow appearance of each test tube media (Table 6).

Table-6: Biochemical characterization of Xoo

\begin{tabular}{|l|c|c|c|c|}
\hline \multirow{2}{*}{\multicolumn{1}{|c|}{ Isolates }} & \multicolumn{4}{c|}{ Biochemical tests } \\
\cline { 2 - 5 } & $\begin{array}{c}\text { MR } \\
\text { Test }\end{array}$ & IP Test & $\begin{array}{c}\text { CU } \\
\text { Test }\end{array}$ & VP Test \\
\hline Hassan pura & - & - & + & - \\
\hline Riazabad & - & - & + & - \\
\hline $\begin{array}{l}\text { Thatha kher-o- } \\
\text { matmal }\end{array}$ & - & - & + & - \\
\hline Sukheki chowki & - & - & + & - \\
\hline Tootra & - & - & + & - \\
\hline Madryanwala & - & - & + & - \\
\hline Hafizabad bypass & - & - & + & - \\
\hline Fatehpur & - & - & + & - \\
\hline Rasoolpur tarar & - & - & + & - \\
\hline Thatha jehadka & - & - & + & - \\
\hline $\begin{array}{l}\text { Tibba shah } \\
\text { behlool }\end{array}$ & - & - & + & - \\
\hline
\end{tabular}

MR (Methyl Red), IP (Indole Production), CU (Citrate Utilization), VP (Voges-Proskaure)

\section{In-vitro management of pathogen by using different antibiotics}

Three different antibiotics were used for the in-vitro control of the pathogen. Four different levels of concentration $(0 \mathrm{ppm}, 50 \mathrm{ppm}, 100 \mathrm{ppm}$ and 150 $\mathrm{ppm}$ ) of chemicals were used. Antibiotic Kanamycin showed much positive response in controlling the spread and multiplication of the pathogen (16.12 $\mathrm{mm}), 15.81 \mathrm{~mm}$ with Streptomycin and $15.81 \mathrm{~mm}$ radial growth was appeared in comparison to Ampicillin. It was obvious that with the increase in concentration of antibiotics the reduction in growth was decreasing that they linked in inversely proportional sequence. From the Tables it is clearly indicated that after 48 hours, Kanamycin at 50ppm concentration gave the maximum average control $(0.69 \mathrm{~mm})$ in all replications while the streptomycin was giving maximum growth control $(3.49 \mathrm{~mm})$ at 50 ppm and Ampicillin was reducing the maximum radial growth $(5.13 \mathrm{~mm})$ at $50 \mathrm{ppm}$.

Kanamycin at 50ppm concentration gave the maximum average control $(0.69 \mathrm{~mm})$ in all replications while the streptomycin was giving maximum growth control $(3.49 \mathrm{~mm})$ at $50 \mathrm{ppm}$ and Ampicillin was reducing the maximum radial growth $(5.13 \mathrm{~mm})$ at $50 \mathrm{ppm}$ (Table 7).

Table-7: Comparison of antibiotics against Xoo

\begin{tabular}{|c|c|c|c|c|}
\hline Level & $\begin{array}{c}\text { Time } \\
(\text { Hours })\end{array}$ & Kanamycin & Streptomycin & Ampicillin \\
\hline $0 \mathrm{ppm}$ & 48 & $4.66 \mathrm{~cd}$ & $5.37 \mathrm{de}$ & $5.68 \mathrm{~h}$ \\
\hline $50 \mathrm{ppm}$ & 48 & $0.69 \mathrm{e}$ & $3.64 \mathrm{f}$ & $5.86 \mathrm{~g}$ \\
\hline $100 \mathrm{ppm}$ & 48 & $5.64 \mathrm{c}$ & $5.68 \mathrm{de}$ & $7.96 \mathrm{e}$ \\
\hline $150 \mathrm{ppm}$ & 48 & $1.69 \mathrm{e}$ & $6.73 \mathrm{c}$ & $5.84 \mathrm{gh}$ \\
\hline $0 \mathrm{ppm}$ & 72 & $3.28 \mathrm{cde}$ & $6.74 \mathrm{c}$ & $11.33 \mathrm{~b}$ \\
\hline $50 \mathrm{ppm}$ & 72 & $1.96 \mathrm{e}$ & $3.49 \mathrm{f}$ & $5.13 \mathrm{i}$ \\
\hline $100 \mathrm{ppm}$ & 72 & $2.91 \mathrm{de}$ & $5.14 \mathrm{e}$ & $6.74 \mathrm{f}$ \\
\hline $150 \mathrm{ppm}$ & 72 & $11.41 \mathrm{~b}$ & $11.33 \mathrm{~b}$ & $8.96 \mathrm{~d}$ \\
\hline $0 \mathrm{ppm}$ & 96 & $16.12 \mathrm{a}$ & $6.21 \mathrm{~cd}$ & $15.81 \mathrm{a}$ \\
\hline $50 \mathrm{ppm}$ & 96 & $2.46 \mathrm{de}$ & $15.81 \mathrm{a}$ & $5.74 \mathrm{gh}$ \\
\hline $100 \mathrm{ppm}$ & 96 & $2.67 \mathrm{de}$ & $5.41 \mathrm{de}$ & $5.74 \mathrm{gh}$ \\
\hline $150 \mathrm{ppm}$ & 96 & $3.36 \mathrm{de}$ & $6.21 \mathrm{~cd}$ & $9.41 \mathrm{c}$ \\
\hline
\end{tabular}

*Means with different letters in each column are significantly different from each other at 5\% level of probability $(\mathrm{LSD}=$

\section{Discussion}

Rice is a primary nourishment for 2.7 billion individuals around the globe is one of the significant grains utilized everywhere throughout the world (Salim et al., 2003; Shivalingaiah and Umesha 2011; Shivalingaiah et al., 2012). Tropical and sub-tropical districts of the world are the significant rice-makers, with $90 \%$ of generation happening in Asia (Jabeen et al., 2012). It is however heartbreaking that such a vital yield is assaulted by numerous sorts of maladies as well as BLB of rice caused by Xoo. As there is no single powerful control measure is accessible against this sickness (Chaudhary et al., 2009). Borines et al. (2003) announced that the utilization of safe cultivars has been the best and prudent method for controlling bacterial leaf curse of rice. In current study, none of the tested cultivars showed immune response against BLB which forces to find alternate ways for sustainable disease management tactics. These results are line with those of early researchers who 
found 23 basmati genotypes susceptible to BLB (Shah, 2008; Zafar et al., 2020). It is the utmost requirement of for the management of this economically important disease by resistance breeding as maximum commercial basmati varieties showed moderately susceptible to highly susceptible response (Khan et al., 2008; Li et al., 2020).

Prompting plant barrier system by the utilization of organic operators is the new plant assurance procedure. Acceptance of systemic resistance by phytochemicals was recorded by numerous laborers (Vanitha et al., 2009; Kong et al., 2020). Phytochemicals are having extraordinary capacity in plant disease management; consequently they are utilized to treat numerous ailments. The green house tests demonstrated that maladies occurrence decreased when seeds treated and sown (Hari et al., 2013).The present study was gone for discovering contrast in the level of resistance appeared by changed genotypes in light of the visual side effects because of BLB contamination and overseeing disease through chemicals. The germplasm utilized for screening against BLB showed variable reaction. No variety was resistant against the disease. Distinction in resistance in rice germplasm was accounted for by less accessibility of safe sources use of pesticides in adjusted frame for the lessening of BLB is additionally a workable management choice (Arshad et al., 2013).The utilization of actuated resistance in plants is a promising, situation cordial procedure for controlling plant ailments; including those caused by microbes (Mohanbabu et al., 2003).

During biochemical characterization of all the collected isolates were showing positive response towards citrate utilization which means that the isolates were gram negative and were consuming carbon as food from provided media. All the isolates were negative towards the indole production test, methyl red test as well as Voges-Proskaure test. Settlements of $X$. oryzae pv. oryzae are moderate developing, mucoid and straw-hued to yellow in shading, the disconnected microscopic organisms recolored pink-red and demonstrated thin viscid mucoid strand showing positive for $\mathrm{KOH}$ dissolvability test and gram negative nature of the microorganisms. An unmistakable zone of hydrolysis was conformed to the bacterial states, when the plates were overwhelmed with Lugol's iodine. Thus the bacterium demonstrated positive for starch hydrolysis (Vera-Cruz et al., 1984).
The chemicals used against BLB displayed changing decrease in disease incidence rate. Among three chemicals it is indicated that after 48 hours, kanamycin at $50 \mathrm{ppm}$ concentration gave the maximum average control $(0.690 \mathrm{~mm})$ in all replications while the streptomycin was giving maximum growth control $(3.49 \mathrm{~mm})$ at $50 \mathrm{ppm}$ and ampicillin was reducing the maximum radial growth $(5.137 \mathrm{~mm})$ at $50 \mathrm{ppm}$.In the $1960 \mathrm{~s}$, various types of agrochemicals were created from rehashed field trials and made available on a vast scale, for the most part in Japan. They depended on chloramphenicol, nickeldimethyldithiocarbamate, dithianon and fentiazon. Most were problematic, however inferable from changeability in affectability among the pathogen populace. In any case, synthetic control of bacterial leaf curse in tropical storm tropical Asia is unfeasible and no genuinely viable bactericide is monetarily accessible for malady control (Lee et al., 2005; Liu et al., 2006). Kanamycin inhibits protein synthesis by tightly binding to the conserved A site of $16 \mathrm{~S}$ rRNA in the $30 \mathrm{~S}$ ribosomal subunit of the bacteria ( $\mathrm{Su}$ et al., 2015).A use of copper-oxychloride and streptomycin totally repressed of bacterial development. A streptomycin blend was tried in India for cleansing of rice seeds and it turned out to be compelling (Srivastava, 1972). The second most effective antibiotic in current study was streptomycin which irreversibly binds to the $16 \mathrm{~S}$ rRNA and S12 protein within the bacterial $30 \mathrm{~S}$ ribosomal subunit. As a result, this agent interferes with the assembly of initiation complex between mRNA and the bacterial ribosome, thereby inhibiting the initiation of protein synthesis (Aktan et al., 2013).Bacterial leaf blight injuries in rice were lessened by utilizing fading powder with $30 \%$ chlorine $(2 \mathrm{~kg} / \mathrm{ha})$ to clean rice seeds (Chand et al., 1979). The antibacterial exercises of various plant removes against plants ailments have been already researched (Okigbo and Nmeka, 2005). Antimicrobials, fungicides, and even organics, for example, dairy animals excrement were endeavored for the control of Bacterial leaf blight of rice, yet up until this point, just a halfway control of the illness has been conceivable (Mary et al., 2001).

The outcomes of the present research are supported by previous experiments as described above. These results would be valuable to manage BLB disease of rice that is an emerging and economically important disease in Pakistan. However, it is necessary to carry out field experiments to prove the effectiveness of these antibiotics because there are many factors in the 
field which influence the chemical control of plant diseases. Further studies for chemical disease control in field conditions are needed.

\section{Conclusion}

None of the cultivars showed resistance against BLB. However, Basmati varieties can be used with appropriate antibiotics. The results of screening provide practical useful information to find out the level of resistance in available rice germplasm. Biochemical characterization would be helpful in devising the probable losses caused by Xoo. The present study suggests that Kanamycin is the most effective antibiotic for the management of Xoo.

\section{Acknowledgment}

The authors are highly obliged to Chairman Department of Plant Pathology (UAF) for providing research area in order to accomplish this research project.

\section{Disclaimer: None.}

Conflict of Interest: None.

Source of Funding: None.

\section{References}

Ahmad N, Raziuddin, Ahad F, Iqbal T, Khan N, Nauman $M$ and Hameed F, 2020. Genetic analysis of biochemical traits in $\mathrm{F} 3$ populations of rapeseed (Brassica napus L.). Asian J. Agric. Biol. 8(4): 491-500. DOI: https://doi.org/10.35495/ajab.2020.03.147

Ahmed TM, Shahid M, Noman MBK, Niazi F, Mahmood I, Manzoor Y, Zhang B, Li Y, Yang C, Yan and Chen J, 2020. Silver nanoparticles synthesized by using Bacillus cereus SZT1 ameliorated the damage of bacterial leaf blight pathogen in rice. Pathogens 9: 160: doi: 10.3390/pathogens9030160.

Akhtar MA, Rafi A and Hameed A, 2008. Comparison of methods of inoculation of Xanthomonas oryzae pv. oryzae in rice cultivars. Pak. J. Bot. 40(5): 2171-2175.

Aktan Y, Tan S and Icgen B, 2013. Characterization of lead-resistant river isolate Enterococcus faecalis and assessment of its multiple metal and antibiotic resistance. Environ. Monit. Assess. 185: 5285-5293.
Arshad HMI, Naureen S, Saleem K, Ali S, Jabeen T and Babar MM, 2013. Morphological and biochemical characterization of Xanthomonas oryzae pv. oryzae isolates collected from Punjab during 2013. Adv. Life Sci. 2(3):125-130.

Basit A, Ahmad I, Rahim K and Shafiq M, 2014. Isolation and identification of phytopathogens from diseased vegetables at district Kohat, Khyber Pakhtunkhwa Pakistan. J. Curr. Res. Sci. 2(4): 221-225.

Borines L, Redona E, Porter B, White F, Vera Cruz $\mathrm{C}$ and Leung H, 2003. Molecular markers for detecting bacterial blight resistance genes in maintainer lines of rice hybrids. In: Advances in Rice Genetics eds Khush GS, Brar DS, Hardy B. (Manila: International Rice Research Institute). pp. 245-247.

Bradbury JF, 1970. Isolation and preliminary study of bacteria from plants. PANS Pest Articles and News Summaries. 16: 632-637.

Chand T, Sing N, Sing H and Thind BS, 1979. Field efficacy of stable bleaching powder to control bacterial blight of rice. Int. Rice Res. Newslett. 4(4): 12-13.

Chaudhary RC, 1996. Internationalization of elite germplasm for farmers: Collaborative mechanisms to enhance evaluation of rice genetic resources. In: New Approaches for Improved use of Plant Genetic Resources; Fukuyi, Japan; pp. 26.

Chaudhary SU, Hussain M, Iqbal $\mathrm{J}$ and Ali MA, 2009. Effect of nitrogen doses on incidence of bacterial leaf blight in rice. J. Agric. Res. 47(3): 253-258.

Furutani A, Takaoka M, Sanada H, Noguchi Y, Oku T, Tsuno K, Ochiai H and Tsuge S, 2009. Identification of novel type III secretion effectors in Xanthomonas oryzae pv. oryzae. Mol. PlantMicrobe Interact. 22: 96-106.

Cheng F,Quan X,Zhengjin X and Wenfu C, 2020. Effect of rice breeding process on improvement of yield and quality in China. Rice Sci. 27(5): 363-367.

Gholve $M$ and Kurundkar, 2007. Efficacy of fungicides and antibiotic against Xanthomonas axonopodis pv. malvacearum under in-vitro condition. Agric. Sci. Digest. 27(1): 73-74.

Hari Y, Srinivasa RK, Viraktamath BC, Hariprasad AS, Laha GS and Ahmed M, 2013. Markerassisted introgression of bacterial blight and blast 
resistance into IR 58025B, an elite maintainer line of rice. J. Plant Breed. 132:586-594.

Herawati R, Ganefianti DW, Pujiwati H, Purwoko BS and Dewi IS, 2021. Assessment of aluminium tolerant of double haploid lines for developing new type of upland rice. Asian J. Agric. Biol. 2021(3): 202005295. DOI: https://doi.org/10.35495/ajab.2020.05.295

Jabeen R, Iftikhar T and Batool H, 2012. Isolation, characterization, preservation and pathogenicity test of Xanthomonas oryzae pv. oryzae causing bacterial leaf blight disease in rice. Pak. J. Bot. 44(1): 261-265.

Jeyalakshmi C, Madhiazhagan K and Rettinassababady C, 2010. Effect of different methods of application of Pseudomonas fluorescens against bacterial leaf blight under direct sown rice. J. Biopest. 3(2): 487-488.

Khan JA, Jamil FF and Gill MA, 2001. Screening of rice varieties/lines against bakanae and bacterial leaf blight (BLB). Pak. J. Phytopath. 12(1): 6-11.

Khan JA, Arshad HMI, Jamil FF and Hasnain S, 2008. Screening of rice germplasm against Bacterial leaf blight disease. Pak. J. Phytopath. 20(1): 48-51.

Klingler JM, Stowe RP, Obenhuber DC, Groves TO, Mishra SK and Pierson DL, 1992. Evaluation of the Biolog automated microbial identification system. Appl. Environ. Microbiol. 58: 2089.

Kong W, Ding L and Xia X, 2020. Identification and characterization of genes frequently responsive to Xanthomonas oryzae pv. oryzae and Magnaporthe oryzae infections in rice. BMC Genomics. 21: 21. doi: 10.1186/s12864-0196438-y.

Lee BM, Park YJ, Park DS, Kang HW, Kim JG, Song ES, Park IC, Yoon UH, Hahn JH, Koo BS, Lee GB, Kim H, Park HS, Yoon KO, Kim JH, Jung CH, Koh NH, Seo JS and Go SJ, 2005. The genome sequence of Xanthomonas oryzae pathovar oryzae KACC10331, the bacterial blight pathogen of rice. Nucleic Acids Res.33: 577-586. doi: 10.1093/nar/gki206.

Li C, Li W, Zhou Z, Chen H, Xie C and Lin Y, 2020. A new rice breeding method: CRISPR/Cas 9 system editing of the Xa promoter to cultivate transgene-free bacterial resistant rice. Plant Biotechnol. J. 18(2): 313-315. doi: 10.1111/pbi.13217.
Liu DON, Ronald PC and Bogdanove AJ, 2006. Xanthomonasoryzaepv. oryzae: Model pathogen of a model crop. Mol. Plant Pathol. 7: 303-324.

Malukani KK, Ranjan A, Hota SJ, Patel HK and Sonti RV, 2020. Dual activities of receptor-like Kinase Os WAKL21.2 induce immune responses. Plant Physiol. 183(3): 1345-1363. doi: 10.1104/pp.19.01579.

Manivannan M, Ganesh P, Kumar RS, Tharmaraj K and Shiney RB, 2012. Isolation, Screening, characterization and antagonism assay of PGPR isolates from Rhizosphere of rice plants in Cuddalore District. Int. J. Pharma. Biol. Arch. 3: 179-185.

Mary CA, Nair SK and Saraswathy P, 2001. Efficacy of prophylactic and curative sprayings on the control of bacterial blight of rice. J. Tropic. Agric. 39: 73-75.

Mohanbabu R, Sajeena A, Vijaya A, Samundeeswari A, Sreedhar A, Vidhyasekeran P and Reddy AM, 2003. Induction of bacterial blight (Xanthomonas oryzae pv. oryzae) resistance in rice by treatment with acibenzolarS-methyl. Ann. Appl. Biol. 143: 333-340

Nino-Liu DO, Ronald PC and Bogdanove AJ, 2006. Xanthomonas oryzae pathovars model pathogens of a model crop. Mol. Plant Pathol. 7: 303-324.

Okigbo RN and Nmeka IA, 2005. Control of yam tuber rot with leaf extracts of Xylopiaaethiopicaand Zingiberofficinale. Afric. J. Biotech. 4(8): 804-807.

Padmaja G, Devi UG, Yugander A, Srinivas C, Rani CVD, Sundaram RM and Laha GS, 2017. Biochemical characterization of Xanthomonas oryzae pv oryzae isolates collected from Telangana and Andhra Pradesh. Ind. J. Plant Protect. 45(2): 193-199.

Rangarajan S,Saleena M, Vasudeva P and Nair S, 2003. Biological suppression of rice disease by Pseudomonas spp. under saline soil conditions. Plant Soil. 251: 73-82.

Salim M, Akram M, Akhtar ME and Ashraf M, 2003. Rice, A production Hand Book. Pakistan Agricultural Research Council, Islamabad. Pakistan.

Sere Y, Onasanya A, Verdier V, Akator K, Ouedraogo LS, Segda Z, Mbare MM, Sido AY and Basso A, 2005. Rice bacterial leaf blight in West Africa: Preliminary studies on disease in farmers' fields and screening 
released varieties for resistance to the bacteria. Asian J. Plant Sci. 4: 577-579.

Shah MA, 2008. Morphological, molecular and resistance (bacterial blight and leaf folder) characterization of wild species of rice and F1 hybrids. Ph.D. Thesis submitted to NWFP Agriculture University, Peshawar, Pakistan.

Shivalingaiah S and Umesha S, 2011. Characterization of Xanthomonas oryzae pv. oryzae from major rice growing regions of Karnataka. The Bioscan. 6: 5-10.

Shivalingaiah S, Umesha and Sateesh MK, 2013. Cocculus hirsutus extract inhibits the Xanthomonas oryzae pv. oryzae, the bacterial leaf blight pathogen in rice. Arch. Phytopathol. Plant Protect. 46(15): 1885-1894.

Shivalingaiah S,Umesha and Sateesh MK, 2012. Molecular detection of Xanthomonas oryzae pv. oryzae in rice seeds. Australasian J. Plant Sci. Biotech. 6(1): 44-47.

Srivastava DN, 1972. Bacterial blight of rice. Ind. Phytopath. 25: 1-16.

Su YB, Peng B, Han Y, Li H and Peng XX, 2015. Fructose restores susceptibility of multidrugresistant Edwardsiella tarda to kanamycin. J. Proteom. Res. 14: 1612-1620. doi: 10.1021/pr501285f.

Sultan F, Al-Farha AA and Shaaban I, 2020. Separation and identification of some fatty acids and phenolic compounds from Portulaca oleracea L. and study their biological effect on two types of pathogenic bacteria. Asian J. Agric. Biol. $\quad 8(3)$ : 281-290. DOI: https://doi.org/10.35495/ajab.2020.02.119

Tailor A and Joshi BH, 2012. Characterization and optimization of siderophore production from Pseudomonas fluorescens strain isolated from sugarcane rhizosphere. J. Environ. Res. Dev. 6(3): 688-694.
Vanitha SC, Niranjan SR, Mortensen $\mathrm{CN}$ and Umesha S, 2009. Bacterial wilt of tomato in Karnataka and its management by Pseudomonas fluorescens. Biocontrol. 54: 685-695.

Velusamy P, Immanuel JE, Gnanamanickam SS and Thomashow LS, 2006. Biological con associated bacteria producing 2,4-diacetylphloroglucinol. Canadian J. Microbiol. 52: 56-65.

Vera-Cruz CM, Gossele F, Kersters K, Segers P, Mooter VD and Swings J, 1984. Differentiation between Xanthomonas campetris pv. oryzae, Xanthomonas campestris pv. oryzicola and the bacterial 'brown blotch' pathogen on rice by numerical analysis of phenotypic features and protein gel electrophoregrams. J. General Microbiol. 130: 2983-2999.

Zafar K, Khan MZ, Amin I, Mukhtar Z, Yasmin S and Arif M, 2020. Precise CRISPR-Cas9 mediated genome editing in super basmati rice for resistance against bacterial blight by targeting the major susceptibility gene. Front. Plant Sci. 11: 575:575. doi: 10.3389/fpls.2020.00575.

\section{Contribution of Authors}

Khan A: Conceived idea, designed research methodology and collected data

Ali S: Supervised research and approved final draft

Sajid M \& Ghani MU: Collected, analysed and interpreted data

Zeshan MA \& Binyamin R: Collected data and wrote \& edited manuscript

Ahmed N: Helped in designing research methodology 